\title{
Water masses, circulation and transport in the eastern boundary current of the North Atlantic subtropical gyre*
}

\author{
ALONSO HERNÁNDEZ-GUERRA ${ }^{1}$, FEDERICO LÓPEZ-LAATZEN², \\ FRANCISCO MACHÍN ${ }^{1}$, DEMETRIO DE ARMAS ${ }^{2}$ and J.L. PELEGRÍ ${ }^{1}$ \\ ${ }^{1}$ Facultad de Ciencias del Mar, Universidad de Las Palmas de Gran Canaria, Canary Islands, Spain. \\ ${ }^{2}$ Instituto Español de Oceanografía, Santa Cruz de Tenerife, Canary islands, Spain.
}

\begin{abstract}
SUMMARY: CTD sections carried out in September 1998 are used to describe the water masses, geostrophic circulation and mass transport in the easternmost branch of the Canary Current. The surface water mass $(<600 \mathrm{~m})$ consists of North Atlantic Central Water (NACW) flowing south with a net mass transport of $2.3 \times 10^{9} \mathrm{~kg} \mathrm{~s}^{-1}$. A tongue of relatively fresh water, consisting of Antarctic Intermediate Water (AAIW), was found approximately in the 600-1100 m depth layer. This tongue was $200 \mathrm{~km}$ wide, stretching from the African coast almost to Gran Canaria Island, and transported a net mass of 1.1 $\mathrm{x} 10^{9} \mathrm{~kg} \mathrm{~s}^{-1}$ northward. This system of currents is what constitutes the real eastern boundary current of the North Atlantic Subtropical Gyre.
\end{abstract}

Key words: water masses, circulation, transport, eastern boundary current, subtropical gyre.

\section{INTRODUCTION}

The meridional circulation of a subtropical gyre consists of intense western boundary currents flowing north, and relatively slow eastern currents flowing south. In the North Atlantic subtropical gyre the eastern current is named the Canary Current. In this paper we will be concerned with the easternmost branch of the Canary Current, which flows south between the Canary Archipelago and the African coast. This current flows along the African coast in the upper main thermocline and may be considered as the real eastern boundary current for the gyre.

It is fair to say that physical oceanographers have usually been more interested in studying the western

\footnotetext{
*Received October 11, 1999. Accepted July 21, 2000.
}

boundary current that the eastern one. This is not surprising due to the intensity of that current. Modeling efforts by Luyten et al.(1983), Pedlosky (1983), and Huang (1989), however, started a real interest in the dynamics of the eastern boundary region, with the so-called 'shadow zone' and 'eastern boundary ventilation' concepts.

There has been some controversy about the way in which the Canary Current is fed. Some studies (e.g., Krauss and Wübber, 1982; Stramma, 1984; Stramma and Siedler, 1988; Fiekas et al., 1992; Navarro-Pérez and Barton, 2001) have suggested that the Canary Current is fed by the easternmost branch of the Azores Current, a current flowing eastward between $30^{\circ} \mathrm{N}$ and $40^{\circ} \mathrm{N}$, and receives no contribution from the Portugal Current, a southward branch of the North Atlantic Current. However, 
other studies (e.g., Dietrich et al., 1980; Wunsch and Grant, 1982; Paillet and Mercier, 1997) have suggested that the Portugal Current does feed the Canary Current. Nevertheless, we have not found any study that has carried out measurements in the easternmost branch of the Canary Current.

Several decades ago some research was carried out in order to understand the dynamics of the fisheries along the west coast of Africa. This was the overall aim of an international program called Cooperative Investigation of the Northern Part of the Eastern Central Atlantic (CINECA) in the 70's. This program was principally focused on studying the dynamics of coastal upwelling off Northwest Africa (Hempel, 1982), and left the study of the Canary Current unattended.

The mesoscale eddy field in the Canary Current is dominated by the presence of the Canary islands in the path of this current and the influence of the upwelling system off Northwest Africa (HernándezGuerra et al., 1993; Arístegui et al., 1994; Arístegui et al., 1997; Barton et al., 1998; Pacheco and Hernández-Guerra, 1999; Barton et al., 2001). The presence of the islands generates cyclonic and anticyclonic eddies downstream the islands, and the influence of the upwelling system consists of upwelling filaments that are entrained into the main current. Despite this, little effort has been made to investigate the intensity of the flux through the Canary Archipelago and between the archipelago and the African coast (however, see Navarro-Pérez and Barton, 2001).
In these study we analyze recent hydrographic data to describe the water masses in the region and to estimate the meridional water mass transport by the Canary Current, as well as to quantify the water mass transport in terms of the water masses.

\section{DATA}

The BIOCAN'98 Project focused on the study of the mesoscale circulation in the Canary Islands region. Within its framework we had the opportunity to carry out two CTD sections perpendicular to the main flow of the area. These sections had been carried out periodically on a bimonthly basis with eXpandeble BathiThermographs (XBT) as part of the CANIGO project.

The data we will show on this occasion consist of 12 CTD stations carried out on board of the R/V Thalassa at a nominal spacing of $13 \mathrm{~km}$ from 19 to 21 September 1998 (Fig. 1). Stations extended to within $50 \mathrm{~m}$ of the bottom, which ranges from around $700 \mathrm{~m}$ on the west side to $300 \mathrm{~m}$ on the east side of each transect. Thus, we covered the whole transect length of each passage.

The CTD system consisted of a MARK IIIC having WOCE recommendations with a rosette G.O., 1015 with 24 water sampling bottles of 12 liters. Standard procedures for in situ calibration and data processing were applied to the data. The data sets are comparable to the potential temperature/salinity relations in the area.

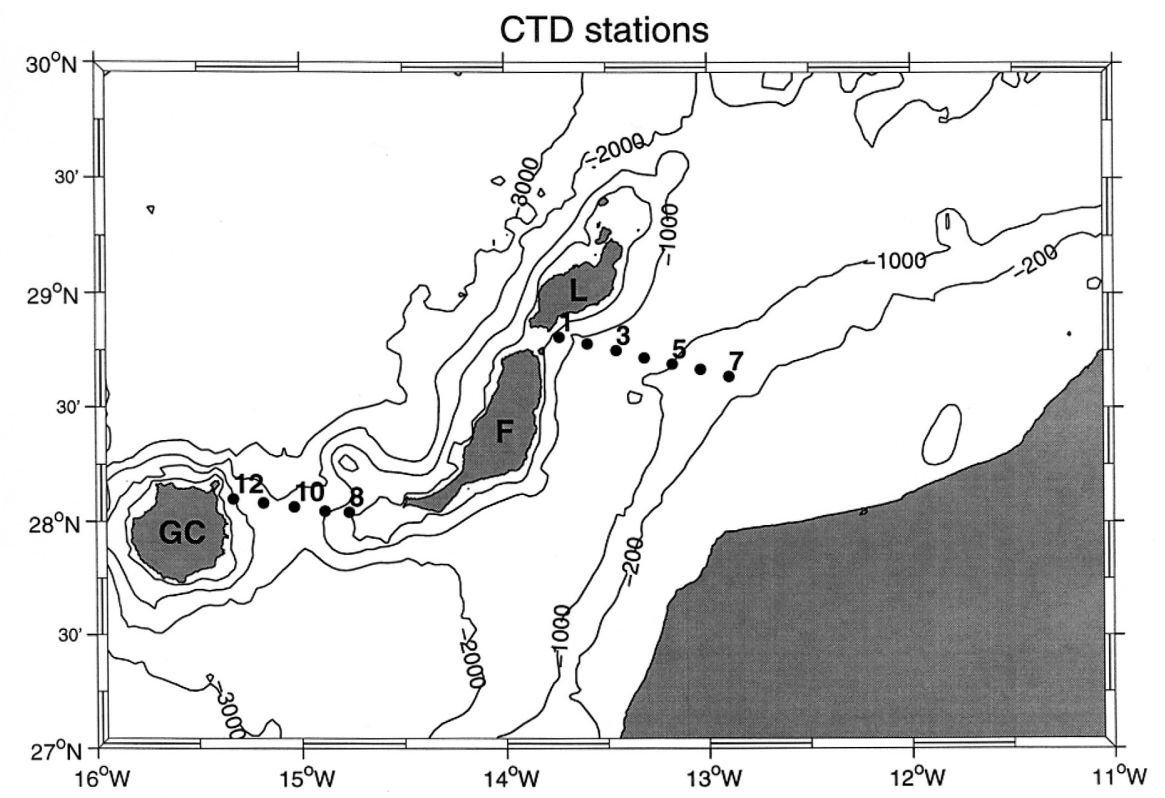

FIG. 1. - Location of the CTD stations for this study. GC stands for Gran Canaria, F stands for Fuerteventura, and L stands for Lanzarote. For reference, the $200 \mathrm{~m}, 1000 \mathrm{~m}, 2000 \mathrm{~m}$, and $3000 \mathrm{~m}$ isobaths are shown. 

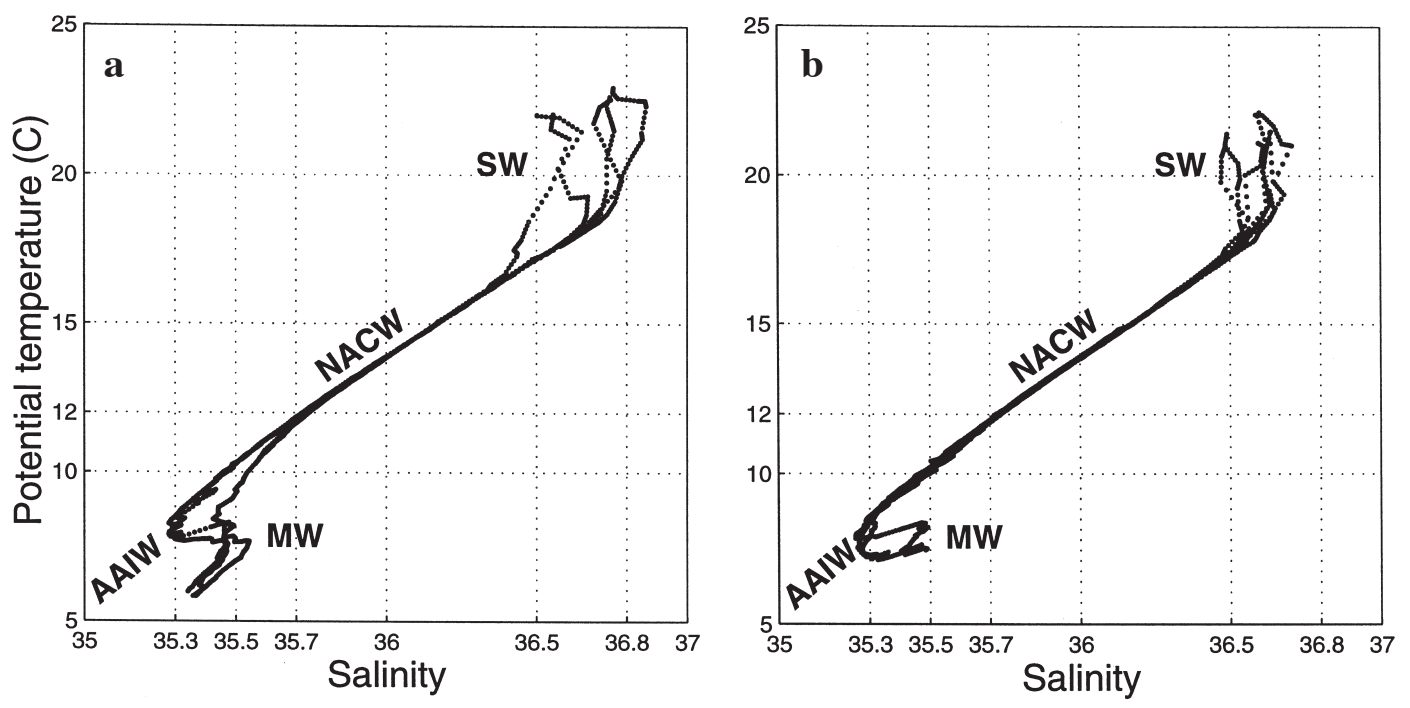

FIG. 2. - Potential temperature/salinity diagrams for Gran Canaria-Fuerteventura section (a), and Lanzarote-African coast section (b).

\section{WATER MASSES AND VERTICAL SECTIONS}

In order to identify the water masses and to relate them with depths and neutral density values, we will show potential temperature/salinity diagrams and vertical sections of neutral density, temperature, and salinity. The neutral density algorithm of Jackett and McDougall (1996) has been used as the 'density' variable throughout this paper, and as a reference level to estimate the geostrophic current. Neutral density values and potential density values are very similar in the upper ocean, and the former can be used in the whole water column to avoid using different potential densities referenced to different depths.

Figures $2 \mathrm{a}$ and $2 \mathrm{~b}$ show the potential temperature/salinity diagrams for the section between Gran Canaria and Fuerteventura (from now on, GC-F), and for the section between Lanzarote and the African coast (from now on, L-A). These figures show different water masses.

Figure 2 (surface waters, $<100 \mathrm{~m}$ ) shows high variability in potential temperature/salinity values. The low salinity values apparently correspond to upwelled waters spreading from the African coast.

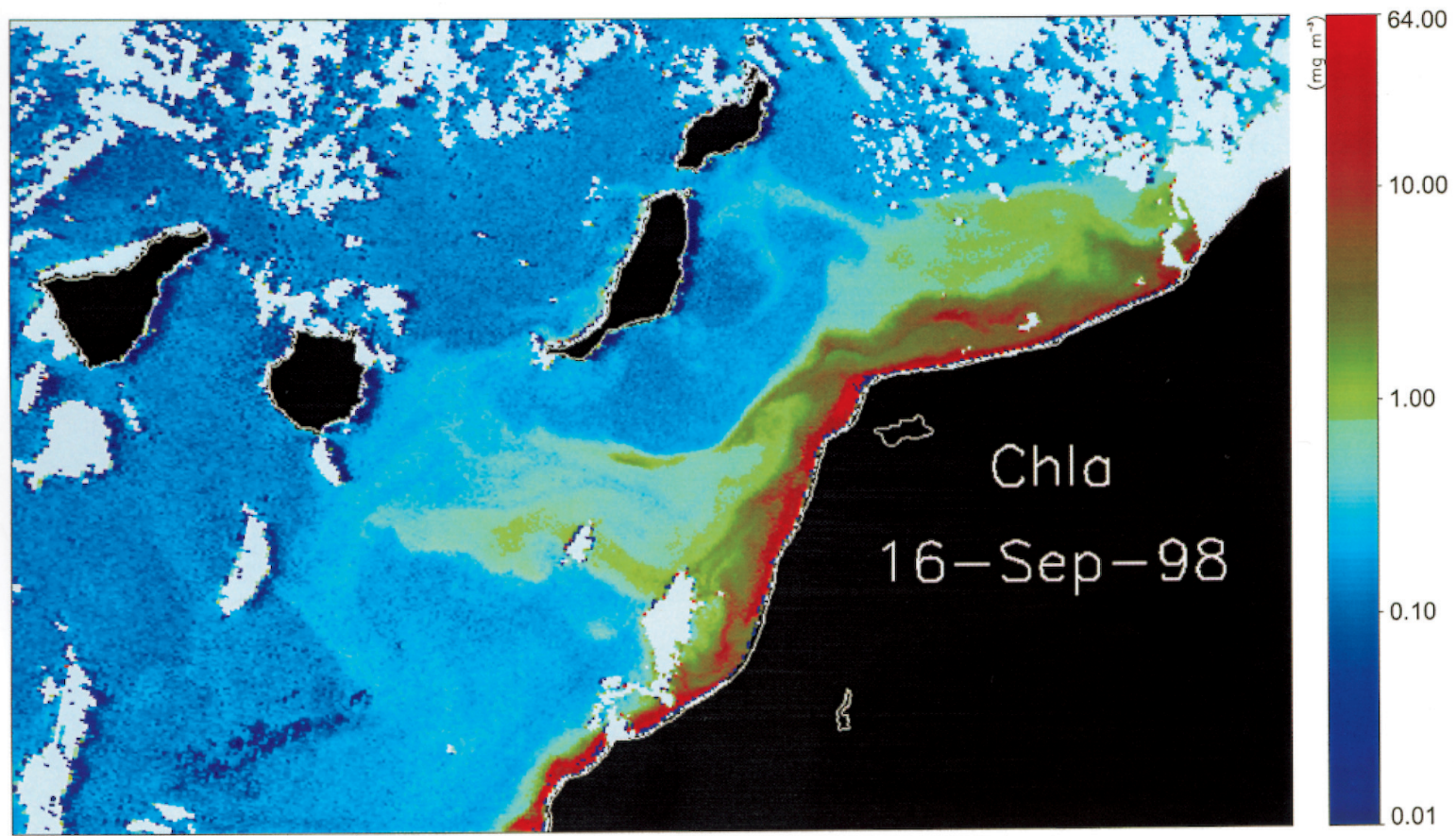

FIG. 3. - Image of phytoplankton pigment concentrations from SeaWifs data corresponding to 16 September 1998 . Notice the upwelling filament generated in the upwelling system off Northwest Africa skirting the east coast of Gran Canaria. 

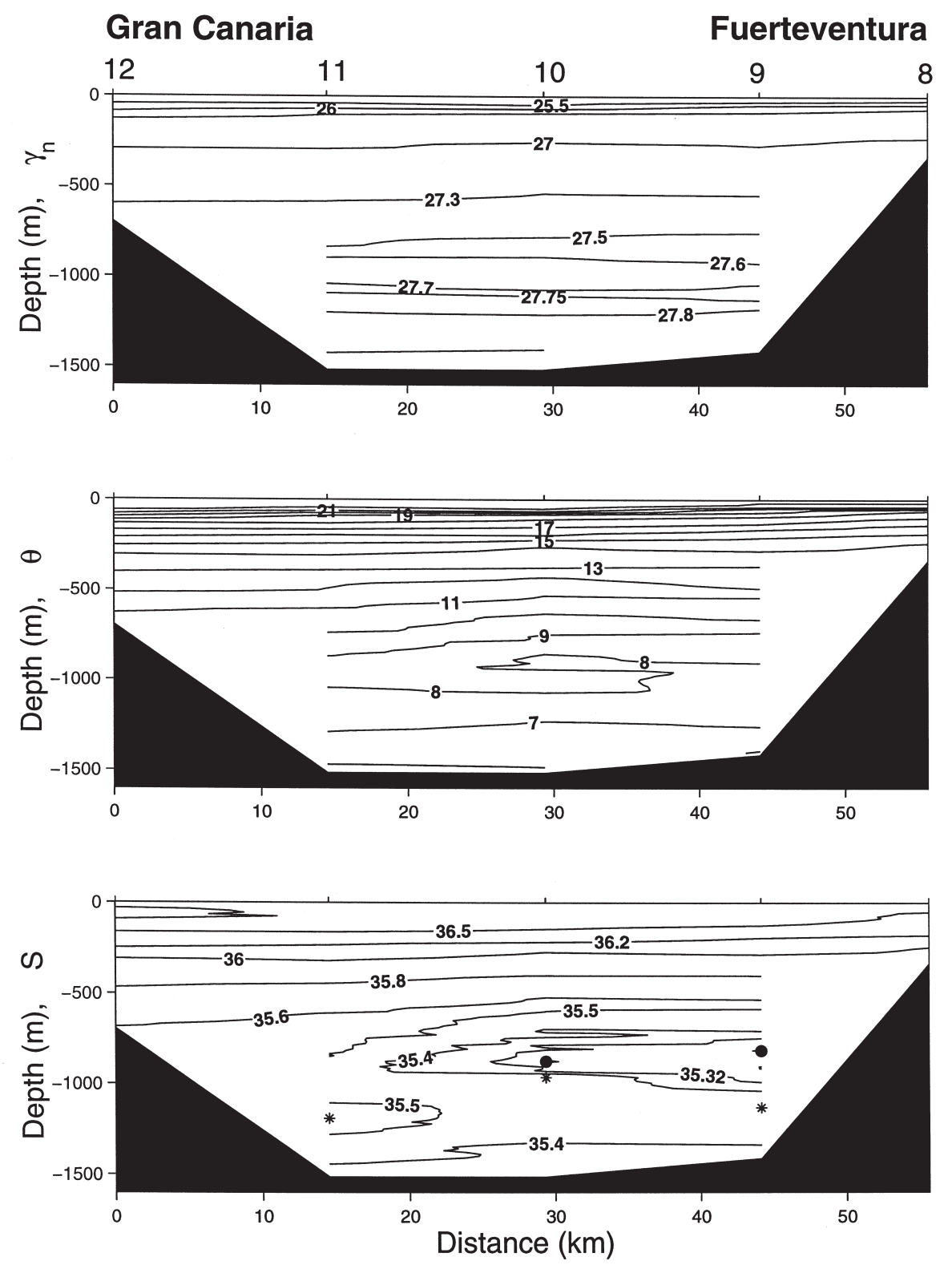

FIG. 4. - Neutral density $\left(\mathrm{kg} / \mathrm{m}^{3}\right.$, upper panel), potential temperature $\left({ }^{\circ} \mathrm{C}\right.$, middle panel), and salinity (lower panel) for the transect between Gran Canaria and Fuerteventura. Solid dots and stars in the salinity transect point out the salinity minimum and maximum at intermediate waters, respectively. Station numbers are at the top. The western end is on the left.

Figure 3, describing phytoplankton pigment concentration, clearly shows an upwelling filament stretching from the African coast and skirting the east coast of Gran Canaria Island. Stations located in the path of this upwelling filament have the smallest surface salinity values (around 36.5 as compared with salinity values around 36.8 at the other stations).

Figure 2 also shows the water masses corresponding to the North Atlantic Central Water (NACW). This is the portion of the potential temperature versus salinity diagram which shows less scatter, and forms the water mass for the main thermocline (Tomczak, 1981). The NACW is character- ized by quasihorizontal isotherms and isohalines as observed in Figures 4 and 5.

Figure 2a shows a spreading of the temperature and salinity isolines that takes place at about $600 \mathrm{~m}$ depth and $27.3 \mathrm{~kg} \mathrm{~m}^{-3}$ neutral density value (around $12^{\circ} \mathrm{C}$ in temperature and 35.7 in salinity). This is the end of the NACW and the start of the lower thermocline.

The lower thermocline is characterized by two intermediate water masses, Antarctic Intermediate Water (AAIW), detected by its fresh anomaly values (salinity values $<35.3$ ), and the warm, high salinity Mediterranean Water (MW) (salinity values $\geq 35.5$ ) (see Fig. 2). 

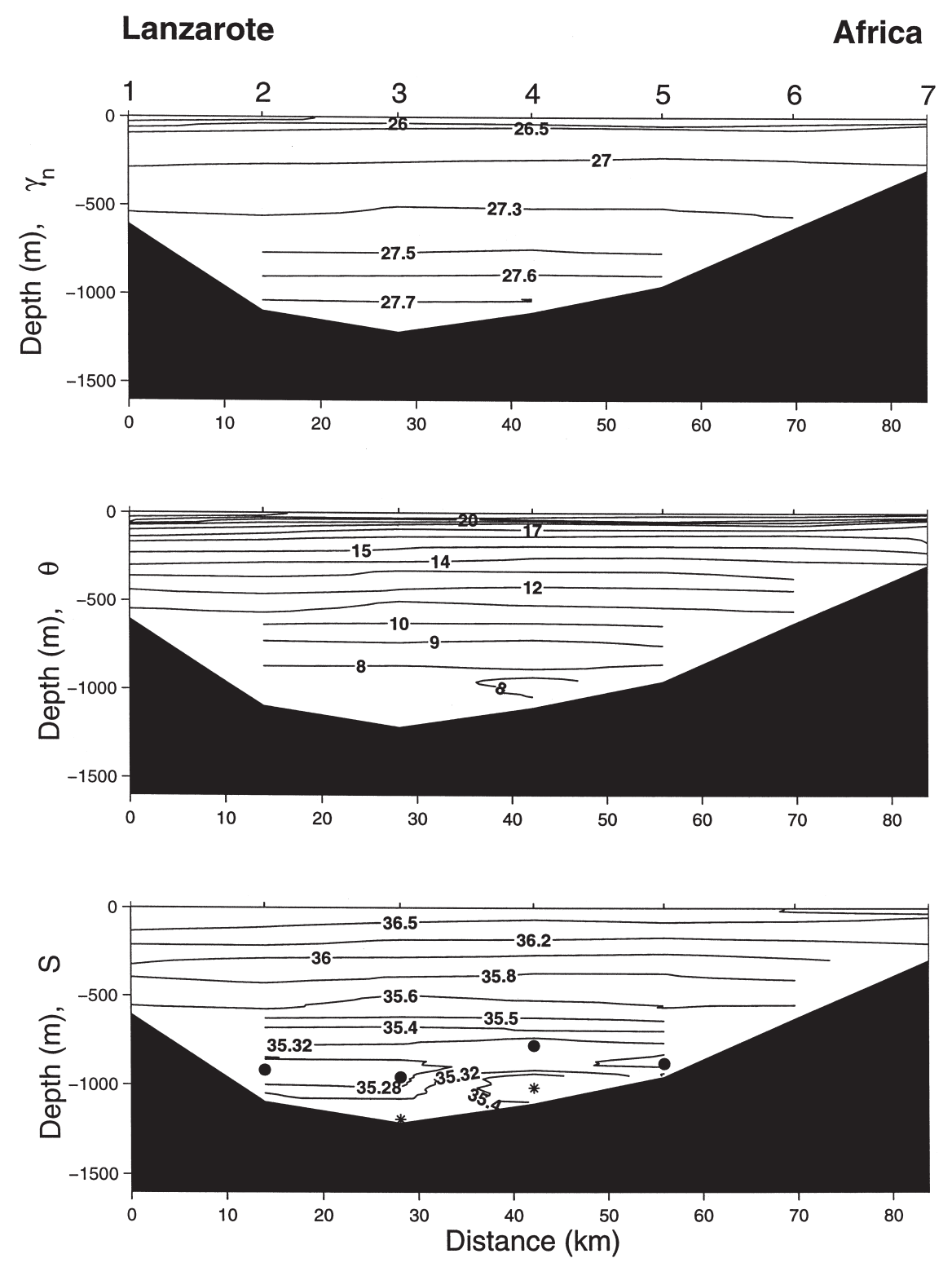

FIG. 5. - Same as Figure 4, but from transect between Lanzarote and the African coast.

Figures 4 and 5, lower panels, show the relative salinity minimum and maximum, respectively, for both transects. Although these values present some scattering in depth, they are approximately located at $900 \mathrm{~m}$ and $1200 \mathrm{~m}$ depth, respectively, coinciding approximately with the neutral density value of 27.6 $\mathrm{kg} \mathrm{m}^{-3}$ for AAIW and $27.8 \mathrm{~kg} \mathrm{~m}^{-3}$ for MW.

The AAIW is clearly observed in the whole L-A section (Fig. 5, lower panel), and in the eastern part of the GC-F section (Fig. 4, lower panel), as the tongue of fresh water centered at $800-900 \mathrm{~m}$ depth. Therefore, it appears that AAIW is transported northward by a current wider than the usual alongshore poleward undercurrent.
All deep enough stations in the GC-F section show MW, as inferred from the potential temperature/salinity diagrams (Fig. 2a). This MW is described as warm and salty water in the lower thermocline, as seen in the middle and lower panels of Figures 4 and 5 (Worthington, 1976; Käse et al., 1986; Reid, 1994; Arhan et al., 1994). Deeper than the MW, North Atlantic Deep Water (NADW) is detected in the transect GC$\mathrm{F}$, the only one deep enough to allow for the existence of this water mass. Because of the small contribution made by these water masses and the coarse spatial resolution of our stations, we will center the following discussion on geostrophic velocity and transport in the NACW and in the AAIW water masses. 


\section{GEOSTROPHIC VELOCITIES AND TRANSPORT}

We have computed the baroclinic part of the geostrophic current using the thermal wind equation. This equation requires a reference level, where the velocity is known, to start integration. Previous studies in the Canary Basin have used a range of 1200-1400 dbar as the level of no motion (Stramma, 1984; Siedler et al., 1985; Stramma and Siedler, 1988; Fiekas et al., 1992), but the L-A section is shallower than this depth range. Many other authors have assumed the depth of no motion to be at the level between two water masses flowing in opposite directions. This assumption has been recently debated: Transient eddies can mask the local mean flow and even filaments of reversed mean flow too narrow to carry clear tracer-properties signatures which may be embedded in the prevailing circulation. However, for this study we have used the water mass diagnostics, which we consider is the best available evidence for the region.

Two water masses flowing in opposite directions may be, in our case, the southward flowing NACW and the northward flowing AAIW. For our geostrophic calculations, therefore, we have taken the neutral density value of $27.3 \mathrm{~kg} \mathrm{~m}^{-3}$ as the reference level, which approximately separates both water masses (see Figs. 4 and 5). In shallow areas, where the bottom neutral density is less than $27.3 \mathrm{~kg}$ $\mathrm{m}^{-3}$ the ocean bottom has been used as the reference surface. Notice that the neutral density value of 27.3 $\mathrm{kg} \mathrm{m}^{-3}$ approximately coincides with the depth of $600 \mathrm{~m}$ throughout the region.

Figure 6 shows the geostrophic velocity in the GC-F section (upper panel) and in the L-A section (lower panel). Both sections show a main core of southward current in the upper $600 \mathrm{~m}$ and northward current in deeper layers. This corresponds to NACW flowing to the south and AAIW flowing to the north.
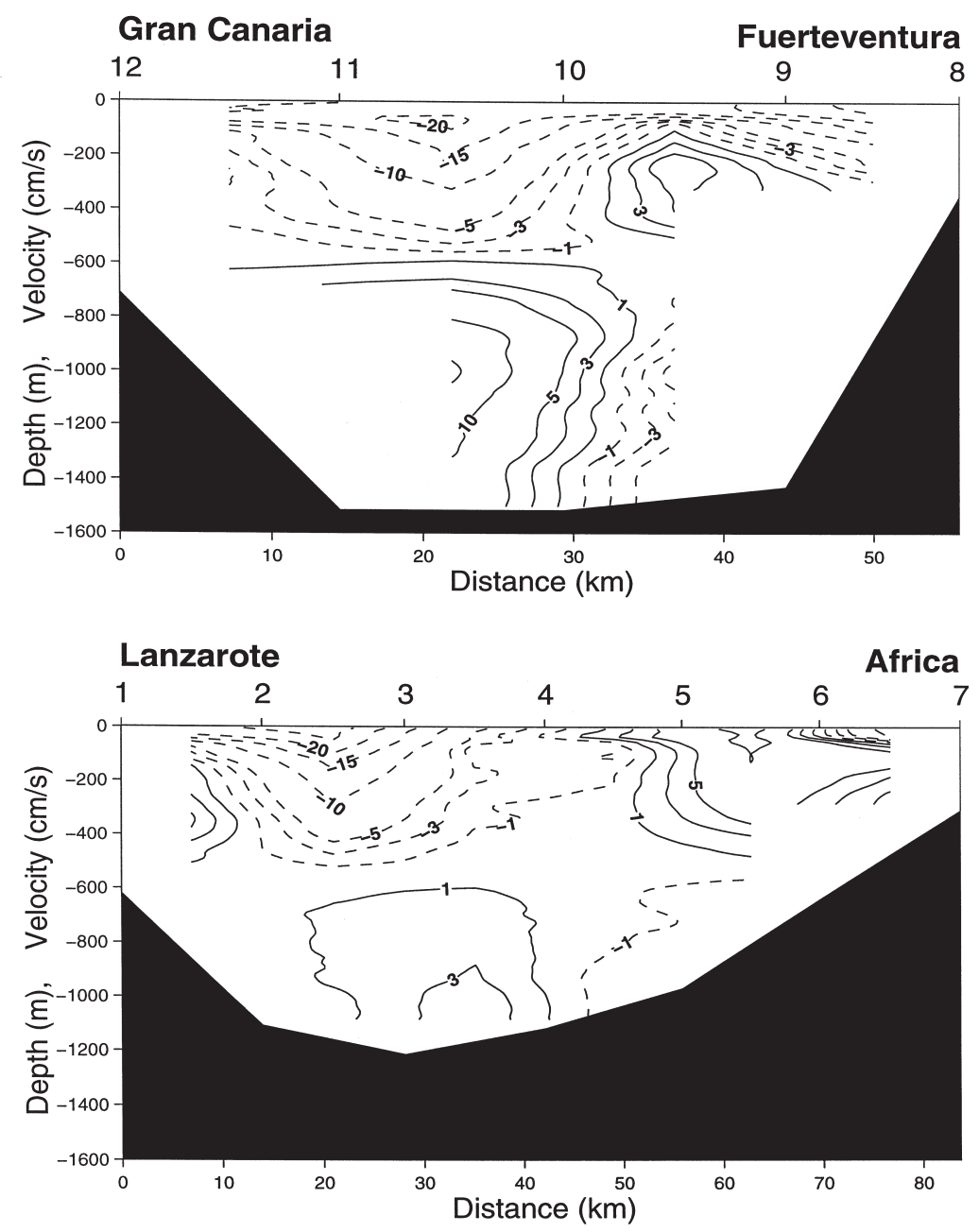

FIG. 6. - Geostrophic current $\left(\mathrm{cm} \mathrm{s}^{-1}\right)$ for the transect between Gran Canaria and Fuerteventura (upper panel), and for the transect between Lanzarote and Africa (lover panel). Southward velocity isolines are dashed. The western end is on the left. 
Thus, we divide the following discussion of geostrophic velocities and mass transport into these two layers. In order to avoid including the MW as part of AAIW, however, we have also integrated the mass transport between $27.3 \mathrm{~kg} \mathrm{~m}^{-3}$ and $27.75 \mathrm{~kg} \mathrm{~m}^{-3}$.

\section{NACW}

Within the upper layer $(<600 \mathrm{~m})$, both sections indicate that the southward geostrophic current $(>20$ $\left.\mathrm{cm} \mathrm{s}^{-1}\right)$ is maximum at the surface and on the western side (Fig. 6). In the L-A section, this location approximately coincides with the highest velocities found from four moorings containing a total of 19 current meters installed in the passage between Lanzarote and the African coast (Müller, personal communication).

At the eastern side of both sections, a weak $(5 \mathrm{~cm}$ $\mathrm{s}^{-1}$ ) northward current may be observed. It has its core at about $300 \mathrm{~m}$ depth in the GC-F section, and at the surface in the L-A section. As seen in the phytoplankton pigment concentration image (Fig. 3), the circulation pattern in the surface waters $(<100$ $\mathrm{m})$ of the Canary Current must be influenced by the entrainment of an upwelling filament.

Cyclonic and anticyclonic eddies are observed downstream of the Canary Islands during all seasons (Pacheco and Hernández-Guerra, 1999). Laboratory and numerical studies have indicated that the generation and shedding of eddies downstream an obstacle depends on the Reynolds number ( $\mathrm{Re}$ ) being higher than a critical value (Boyer, 1970; Boyer and Davies, 1982; Sangrá, 1995). Re is defined as $R e=U L / A_{H}$, where $U$ is the fluid velocity, $L$ is a typical horizontal dimension of the obstacle, and $A_{H}$ is the horizontal eddy viscosity coefficient of the fluid. All islands involved in this study have similar L (around $50 \mathrm{~km})$. Taking $\mathrm{A}_{\mathrm{H}}$ as a constant value $\left(10^{-2} \mathrm{~m}^{2} \mathrm{~s}^{-1}\right)$, the only parameter to determine is the velocity of the fluid, in our case, the velocity of the Canary Current. Although the time variability of the velocity of the Canary Current remains to be determined, at least in September, the estimated velocity is higher than $20 \mathrm{~cm}$ $\mathrm{s}^{-1}$ and large enough to generate and shed eddies.

Figure 7 (upper panel) shows the accumulated mass transport for each section. The dashed line between station pairs 9-8 and 1-2 separates the transect GC-F from the transect L-A. The shallowest layer carries mainly NACW and presents a net southward mass transport of $1.7 \times 10^{9} \mathrm{~kg} \mathrm{~s}^{-1}$ in the GC-F section, and $0.6 \times 10^{9} \mathrm{~kg} \mathrm{~s}^{-1}$ in the L-A section. This gives a net southward mass transport of $2.3 \mathrm{x}$
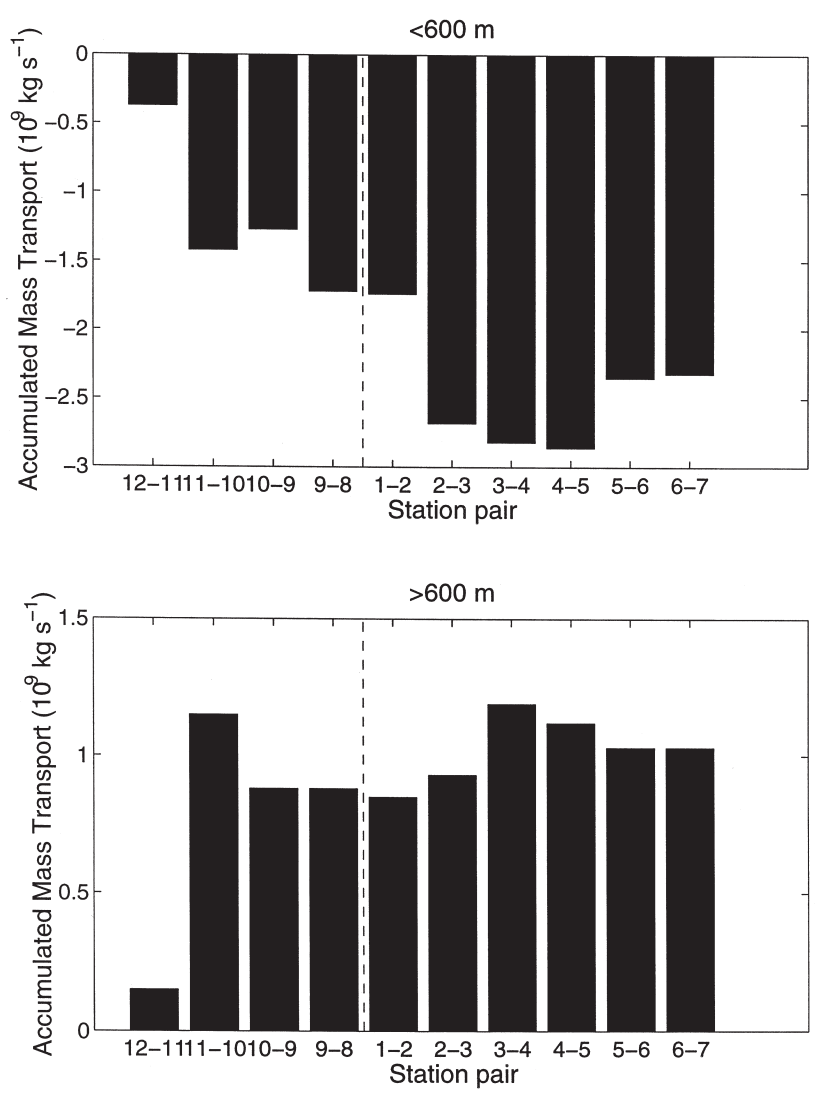

FIG. 7. - Meridional accumulated mass transport $\left(10^{9} \mathrm{Kg} \mathrm{s}^{-1}\right)$ between Gran Canaria and Fuerteventura, and between Lanzarote and the African coast. The upper panel shows mass transport for the layer shallower than the neutral density value of $27.3 \mathrm{Kg} \mathrm{m}^{3}$ corresponding to approximately $600 \mathrm{~m}$ depth, fundamentally NACW. The lower panel shows mass transport for the layer between 27.3 $\mathrm{Kg} \mathrm{m}^{3}$ and $27.75 \mathrm{Kg} \mathrm{m}^{3}$, fundamentally AAIW. The dashed line between station pair 9-8 and 1-2 separates the Gran CanariaFuerteventura transect from the Lanzarote-African coast transect. Notice the different y scale for both panels.

$10^{9} \mathrm{~kg} \mathrm{~s}^{-1}$. The strongest mass transport is at the station pair 11-10 in transect GC-F $\left(1.0 \times 10^{9} \mathrm{~kg} \mathrm{~s}^{-1}\right.$, southward), and at the station pair 2-3 in transect LA $\left(0.9 \times 10^{9} \mathrm{~kg} \mathrm{~s}^{-1}\right.$, southward $)$. The other station pairs give no appreciable contribution to the net mass transport and may be considered as mesoscale eddy variability of the main flow.

Ekman mass transport should be added to the above mass transport. The predominant winds in this region are the Trade Winds which blow southwestward. Thus, the Ekman mass transport is not expected to contribute significantly to this meridional net mass transport and has not been estimated..

Our results agree with the order of magnitude of the geostrophic mass transport of the Canary Current, as estimated from previous investigations. However, we have to take into account that those previous studies focused on the whole eastern boundary current system, and not on the easternmost branch. Thus, 
Dietrich et al. (1980) estimated a volume transport of $14 \times 10^{6} \mathrm{~kg} \mathrm{~s}^{-1}$ between the Azores and Portugal above $1000 \mathrm{~m}$ depth, with $4 \times 10^{6} \mathrm{~kg} \mathrm{~s}^{-1}$ corresponding to the Portugal Current. Saunders (1982) and Stramma (1984) computed a transport of about $11 \mathrm{x}$ $10^{6} \mathrm{~kg} \mathrm{~s}^{-1}$ in the upper $1000 \mathrm{~m}$ between $35^{\circ} \mathrm{W}$ and the African coast. According to Stramma (1984), most of the inflow of $11 \times 10^{6} \mathrm{~kg} \mathrm{~s}^{-1}$ turns to the south in the central east Atlantic, but a small amount $\left(4-5 \times 10^{6} \mathrm{~kg}\right.$ $\mathrm{s}^{-1}$ ) reaches the near coastal region and feeds the Canary Current. Similarly, Käse et al. (1986) presented a map of temperature at $570 \mathrm{~m}$ showing a strong horizontal gradient near the Canary Islands indicating a volume transport of $8 \times 10^{6} \mathrm{~kg} \mathrm{~s}^{-1}$ above $800 \mathrm{~m}$ depth for the Canary Current. More recently, Arhan et al. (1994) and Paillet and Mercier (1997) estimated a value of 5-6 x $10^{6} \mathrm{~kg} \mathrm{~s}^{-1}$ as the net volume transport of the whole Canary Current.

\section{AAIW}

Figure 6 shows that the deep layer $(>600 \mathrm{~m})$ has a higher velocity (about $10 \mathrm{~cm} \mathrm{~s}^{-1}$ ) in the GC-F section (upper panel) than in the L-A section (about $3 \mathrm{~cm} \mathrm{~s}^{-1}$ ). On the eastern side of both sections, a weak southward current of approximately $1 \mathrm{~cm} \mathrm{~s}^{-1}$ is observed.

Figure 7 (lower panel) shows that both sections have a northward mass transport in the layer below $600 \mathrm{~m}$, with values of $0.9 \times 10^{9} \mathrm{~kg} \mathrm{~s}^{-1}$ in the GC-F section, and $0.2 \times 10^{9} \mathrm{~kg} \mathrm{~s}^{-1}$ in the L-A section. Thus, the net mass transport is $1.1 \times 10^{9} \mathrm{~kg} \mathrm{~s}^{-1}$ northward, and corresponds to AAIW. The strongest mass transport is at the station pair 11-10 in the transect GC-F (1.0 x $10^{9} \mathrm{~kg} \mathrm{~s}^{-1}$, southward), and at the station pair 3-4 in the transect L-A $\left(0.3 \times 10^{9} \mathrm{~kg} \mathrm{~s}^{-1}\right.$, southward).

The classical picture of the spreading of AAIW from the South Atlantic to the North Atlantic comes from studies by Wüst (1935) and Iselin (1936). These and more recent works (Mann et al., 1973; Richardson, 1977; Reid, 1994) found AAIW in the whole Atlantic from $50^{\circ} \mathrm{S}$ to $20^{\circ} \mathrm{N}$, and up to Cape Hatteras along the western boundary margin. These studies have used low salinity values at intermediate depths as an indicator of the AAIW circulation pattern. Tsuchiya (1989) used high concentration of silicate as a definition of AAIW and traced this water mass, as transported by the Gulf Stream-North Atlantic Current, as far as the south of Iceland. It is remarkable, however, that in none of these previous studies there is mention of AAIW as far north as $20^{\circ} \mathrm{N}$ along the eastern boundary.
Roemmich and Wunsch (1985), however, showed the results of a transatlantic section starting at $28^{\circ} \mathrm{N}$ in mid 1981 . They described a northward current of low salinity waters in the eastern boundary at intermediate depths as far as $1000 \mathrm{~km}$ from the African coast, and velocities up to $0.5 \mathrm{~cm} \mathrm{~s}^{-1}$.

Recently, Fratantoni and Richardson (1999) deployed a neutrally buoyant SOFAR float at depths of $950-1150 \mathrm{~m}$ in the Eastern Tropical Atlantic Ocean (approximately at $10^{\circ} \mathrm{N}-25^{\circ} \mathrm{W}$ ). The float drifted northward and eastward upon reaching the $2000 \mathrm{~m}$ isobath west of Dakar $\left(14^{\circ} \mathrm{N}\right)$, where it rapidly drifted northward with speeds of $8 \mathrm{~cm} \mathrm{~s}^{-1}$. The buoy then followed a trajectory parallel to, and within $\sim 150 \mathrm{~km}$ of the eastern boundary until near $22^{\circ} \mathrm{N}$, where it drifted westward into the interior ocean. This was presumably caused by an eddy displacing the float offshore.

These previous results together with our evidence, point to the likely existence of an eastern boundary connection between the equatorial and subtropical Atlantic. This connection is particularly relevant to the Atlantic meridional overturning circulation because the northward return flow of surface and intermediate waters, as a result of the highlatitude deep water formation, has been assumed to occur only near the western boundary of the subtropical gyre.

\section{CONCLUSIONS}

In this paper we have used a number of CTD sections in the eastern North Atlantic Subtropical Gyre with the objective of studying the water masses and circulation patterns in the easternmost branch of the Canary Current, what we believe constitutes the real eastern boundary current of the gyre.

The water masses fundamentally consisted of $\mathrm{NACW}$, from the surface down to about $600 \mathrm{~m}$ depth (a neutral density of $27.3 \mathrm{~kg} \mathrm{~m}^{-3}$ ), and AAIW, which forms a tongue about $500 \mathrm{~m}$ thick and $200 \mathrm{~km}$ wide (from the African coast almost as far as Gran Canaria Island).

At the time of the measurements the shallowest layer ( $<100 \mathrm{~m}$ deep) was influenced by an upwelling filament longer than $200 \mathrm{~km}$ starting off the African coast and skirting Gran Canaria Island, which is visible in satellite imagery.

The upper layer flow $(<600 \mathrm{~m})$ consists essentially of NACW and presents strong southward velocities $\left(>20 \mathrm{~m} \mathrm{~s}^{-1}\right)$, with some counter and undercur- 
rents. This velocity is large enough to generate and shed eddies downstream of the islands, being responsible for the strong mesoscale variability in the region.

The net mass transport for the upper layer was $2.3 \times 10^{9} \mathrm{~kg} \mathrm{~s}^{-1}$ southward, similar to previous studies of the whole Canary Current. The mass transport is larger in the Gran Canaria-Fuerteventura passage $\left(1.7 \times 10^{9} \mathrm{~kg} \mathrm{~s}^{-1}\right)$ than in the Lanzarote-African coast passage $\left(0.6 \times 10^{9} \mathrm{~kg} \mathrm{~s}^{-1}\right)$. This is apparently related to the seasonal offshore displacement of the Canary Current (Stramma and Siedler, 1988).

The deeper layer (between approximately $600 \mathrm{~m}$ and $1100 \mathrm{~m}$ ) corresponds to AAIW. This water mass flows north with maximum velocities higher than 10 $\mathrm{cm} \mathrm{s}^{-1}$ in the Gran Canaria-Fuerteventura passage and 3 $\mathrm{cm} \mathrm{s}^{-1}$ in the Lanzarote-African coast passage. The net mass transport was $1.1 \times 10^{9} \mathrm{~kg} \mathrm{~s}^{-1}$, the contribution in the GC-F passage being as much as $0.9 \times 10^{9} \mathrm{~kg} \mathrm{~s}^{-1}$.

The northward current detected at intermediate depths along the African coast could follow the path described by Fratantoni and Richardson (1999) along an Eastern Boundary Layer. This northward flow provides evidence of a possible eastern boundary connection between the equatorial and subtropical Atlantic, particular relevant to the Atlantic meridional overturning.

\section{ACKNOWLEDGEMENTS}

We wish to acknowledge the support of the European Union under CANIGO project (MAS-CT960060) and the Gobierno Autónomo de Canarias (PI1998/066). We also want to thank the Instituto Español de Oceanografía for ship time of the R/V Thalassa. Part of this study was carried out when the first author spent a sabbatical year at Woods Hole Oceanographic Institution. He acknowledges the grant received from the Secretaría de Estados de Universidades, Investigación y Desarrollo. We further thank three anonymous reviewers for helping to improve the manuscript. The satellite image used in this study was received and processed at the Universidad de Las Palmas de Gran Canaria under a FEDER contract (1FD97-1167).

\section{REFERENCES}

Arhan, M., A. Colin de Verdière and L. Mémery. - 1994. The Eastern Boundary of the Subtropical North Atlantic. J. Phys. Oceanogr., 24: 1295-1316.
Arístegui, J., P. Sangrá, S. Hernández-León, M. Cantón, A. Hernández-Guerra and J.L. Kerling. - 1994. Island-induced eddies in the Canary Islands. Deep-Sea Res., 41: 1509-1525.

Arístegui, J., P. Tett, A. Hernández-Guerra, G. Basterretxea, M.F. Montero, K. Wild, S. Hernández-León, M. Cantón, J.A. García-Braun, M. Pacheco and E.D. Barton. - 1997. The influence of island-generated eddies on chlorophyll distribution: a study of mesoscale variation around Gran Canaria. Deep-Sea Res., 44: 71-96.

Barton, E.D., J. Arístegui, P. Tett, M. Cantón, J. García-Braun, S. Hernández-León, L. Nykjaer, C. Almeida, J. Almunia, S. Ballesteros, G. Basterretxea, J. Escánez, L. García-Weill, A. Hernández-Guerra, F. López-Laatzen, R. Molina, M.F. Montero, E. Navarro-Pérez, J.M. Rodríguez, K. van Lenning, H. Vélez and K. Wild. - 1998. The transition zone of the Canary Current upwelling region. Prog. Oceanogr., 41: 455-504.

Barton, E.D., P. Flament, H. Dodds and E.G. Mitchelson-Jacob. 2001. Mesoscale structure viewed by SAR and AVHRR near the Canary Islands. Sci. Mar., 65(Suppl. 1): 167-175

Boyer, D.L. - 1970. Flow past a right circular cylinder in a rotating frame. J. Basic Engin., 92: 430-436.

Boyer, D.L. and P.A. Davies. - 1982. Flow past a circular cylinder on a beta plane. Phil. Trans. Roy. Soc., A, 306: 533-556.

Dietrich, G., K. Kalle, K. Krauss and G. Siedler. - 1980. General Oceanography (translated by H.U. Roll). Willey, New York, $626 \mathrm{pp}$.

Fiekas, V., J. Elken, T. Müller, A. Aitsam and W. Zenk. - 1992. A view of the Canary Basin thermocline circulation in winter. $J$. Geophys. Res., 97: 12,495-12,510.

Fratantoni, D. and P.L. Richardson. - 1999. SOFAR float observations of an intermediate-depth Eastern Boundary Current and mesoscale variability in the Eastern Tropical Atlantic Ocean. $J$. Phys. Oceanogr., 29, 1265-1278.

Hempel, G. (ed.). - 1982. The Canary Current: studies of an upwelling system. Rapp. Procès-Verbaux Réun., Cons. Int. explo. Mer, 455 pp., Copenhagen, Denmark.

Hernández-Guerra, A., J. Arístegui, M. Cantón and L. Nykjær. 1993. Phytoplankton pigment patterns in the Canary Islands area as determined using Coastal Zone Colour Scanner data. Int. J. Rem. Sens., 14: 1,431-1,437.

Huang, R.X. - 1989. The generalized eastern boundary conditions and the three dimensional structure of the ideal fluid thermocline. J. Geophys. Res., 94: 4855-4865.

Iselin, C.O'D. - 1936, A study of the circulation of the western North Atlantic. Pap. Phys. Oceanogr. Met, 4, $101 \mathrm{pp}$.

Jackett, D., and T.J. McDougall. - 1996. A neutral density variable for the world's ocean. J. Phys. Oceanogr., 96: 237-263.

Käse, R.H., J.F. Price, P.L. Richardson and W. Zenk. - 1986. A quasi-synoptic survey of the thermocline circulation and water mass distribution within the Canary Basin. J. Geophys. Res., 91: 9739-9748.

Krauss, W.C. and C. Wübber. - 1982. Response of the North Atlantic to annual wind variations along the eastern coast. Deep-Sea Res., 29: 851-868.

Luyten, J.R., J. Pedlosky and H. Stommel. - 1983. The ventilated thermocline. J. Phys. Oceanogr., 13: 292-309.

Mann, C.R., A.R. Coote and D.M. Garner. - 1973. The meridional distribution of silicate in the western Atlantic ocean. Deep-Sea Res., 20: 791-801.

Navarro-Pérez E. and E.D. Barton. - 2001. Seasonal and interannual variability of the Canary Current. Sci. Mar., 65(Suppl. 1): 205-213

Pacheco, M.M. and A. Hernández-Guerra. - 1999. Seasonal variability of recurrent phytoplankton pigment patterns in the Canary Islands area. Int. J. Rem. Sens., 20: 1405-1418.

Paillet, J. and H. Mercier. - 1997. An inverse model of the eastern North Atlantic general circulation and thermocline ventilation. Deep-Sea Res., 44: 1293-1328.

Pedlosky, J. - 1983. Eastern boundary ventilation and the structure of the thermocline. J. Phys. Oceanogr., 13: 2038-2044.

Reid, J.L. - 1994. On the total geostrophic circulation of the North Atlantic Ocean: Flow patterns, tracers, and transports. Prog. Oceanogr., 33: 1-92.

Richardson, P.L. - 1977. On the crossover between the Gulf Stream and the Western Boundary Undercurrent. Deep-Sea Res., 24: 139-159.

Roemmich, D. and C. Wunsch. - 1985. Two transatlantic sections: meridional circulation and heat flux in the subtropical North 
Atlantic Ocean. Deep-Sea Res., 32: 619-664.

Sangrá P. - 1995. Perturbación de un flujo geofísico por un obstáculo: aplicación a la isla de Gran Canaria. Ph.D. Thesis, Universidad de Las Palmas de Gran Canaria.

Saunders, P.M. - 1982. Circulation in the eastern North Atlantic $J$. Mar. Res., 40 (Suppl.): 641-657.

Siedler, G., W. Zenk and W.J. Emery. - 1985, Strong current events related to a subtropical front in the Northeast Atlantic. J. Phys. Oceanogr., 15: 885-897.

Stramma, L. - 1984. Geostrophic transport in the warm water sphere of the eastern subtropical North Atlantic. J. Mar. Res., 42: 537-558.

Stramma, L. and G. Siedler. - 1988. Seasonal changes in the North Atlantic subtropical gyre. J. Geophys. Res., 93: 8,111-8,118.
Tomczak, M. - 1981. An analysis of mixing in the frontal zone of South and North Atlantic central water off Northwest Africa. Prog. Oceanogr., 10: 173-192.

Tsuchiya, M. - 1989. Circulation of the Antarctic Intermediate Water in the North Atlantic. J. Mar. Res., 47: 747-755.

Worthington, L.V. - 1976. On the North Atlantic Circulation. Johns Hopkins Oceanographic Studies. The Johns Hopkins University Press, 6, $110 \mathrm{pp}$.

Wunsch, C. and B. Grant. - 1982. Towards the general circulation of the North Atlantic Ocean. Prog. Oceanogr., 11: 1-59.

Wüst, G. - 1935. Schichtung und zirukulatin des Atlantischen Ozeans. Die stratosphäre des Atlantischen Ozeans. Wiss. Ergebn. Deutsch. Atlant. Exp. 'Meteor', 6: 109-288. 